\title{
Multi-level governance tackling the COVID-19 pandemic in
} China

Niedja de Andrade e Silva Forte dos Santos 1

1 Universidade de Lisboa / CAPP Centre for Public Administration and Public Policies of the Institute of Social and Political Sciences, Lisbon - Portugal

This paper investigates China's leadership over intergovernmental and private actions in tackling the COVID-19 pandemic and identifies sectors, levels, and roles played. The main argument is that successful control over the pandemic depends on effective and integrated leadership at different levels. The conceptual, theoretical, and analytical framework is given by the multi-level governance theory. Through a case study, the actions adopted in China $(n=374)$ were mapped from reports issued by the Chinese government, the World Health Organization, and media information. Content analysis was adopted to categorize data. Quantitative and qualitative findings show different roles of actors, as well as usefulness of the multi-level governance to provide fast and complex responses required during the pandemic. In the last section, the conclusion and recommendations for future research are addressed. The lack of studies on the application of multi-level governance in non-democratic regimes especially during a pandemic indicates the relevance and contribution of this study to the literature.

Keywords: COVID-19; pandemic; China; multi-level governance.

\section{A governança multinível no enfrentamento da pandemia de COVID-19 pela China}

$\mathrm{O}$ artigo objetiva investigar a liderança pública das ações, relações privadas e intergovernamentais da China no enfrentamento da pandemia de COVID-19, identificando setores e níveis envolvidos, bem como os papéis desempenhados. $\mathrm{O}$ argumento central é o de que o controle bem sucedido da pandemia depende da liderança eficaz e integrada das relações intergovernamentais e privadas nos diversos níveis. O enquadramento conceitual, teórico e analítico é dado pela teoria da governança multinível. Através do método de estudo de caso, as ações de enfrentamento adotadas na China $(n=374)$ foram mapeadas a partir dos relatórios emitidos pelo governo chinês, pela Organização Mundial da Saúde e informações da mídia. As ações foram categorizadas através da técnica de análise de conteúdo. Resultados quantitativos e qualitativos são apresentados e mostram os papéis dos atores, bem como a relevância da governança multinível diante da rápida e complexa resposta exigida pela emergência da pandemia. Na última seção são apresentadas as conclusões e oportunidades para desenvolvimentos futuros. A relevância da pesquisa também reside na escassez de estudos sobre a aplicação da governança multinível em regimes não democráticos, especialmente durante pandemias.

Palavras-chave: COVID-19; pandemia; China; governança multinível.

\section{Gobernanza multinivel en China para el combate de la pandemia de COVID-19}

El artículo investiga el liderazgo público de China en las acciones y relaciones intergubernamentales y privadas para enfrentar la pandemia de COVID-19, al identificar los sectores y niveles involucrados, así como los roles. El argumento central es que el control exitoso de la pandemia depende de un liderazgo efectivo e integrado a diferentes niveles. La teoría de gobernanza multinivel es el marco conceptual, teórico y analítico. Las acciones adoptadas en China $(n=374)$ se mapearon a través del método de estudio de caso, a partir de informes emitidos por el gobierno chino, la Organización Mundial de la Salud e información de los medios y, para categorizar esos datos, se adoptó la técnica de análisis de contenido. Se presentan hallazgos cuantitativos y cualitativos que muestran los roles de los actores, así como la relevancia de la gobernanza multinivel ante la respuesta rápida y compleja requerida por la emergencia pandémica. En la última sección se exponen las conclusiones y recomendaciones para futuras investigaciones. La falta de estudios sobre la aplicación de la gobernanza multinivel en regímenes no democráticos, especialmente durante una pandemia, demuestra la relevancia de este estudio y su contribución a la literatura. Palabras clave: COVID-19; pandemia; China; gobernanza multinivel. 


\section{INTRODUCTION}

\subsection{Overview}

China was the first country to face the pandemic. The WHO technical report praises measures taken by China in tackling the COVID-19 (World Health Organization [WHO], 2020a, p. 16). In this regard, China has undertaken a pronged strategy with national and international actions on health surveillance, treatment, research, social regulation and public management. By March 2020, China controlled the pandemic supported by a wide range of stakeholders (Ghebreyesus, 2020). Despite being accused of imposing authoritarian arrangements (Breuninger, 2020; Campbell \& Doshi, 2020; Graham-Harrison \& Kuo, 2020), China's efficiency has been internationally recognized (WHO, 2020a).

Thus, this paper analyzes the leadership of China in coping COVID-19 from the perspective of multi-level governance theory. The main argument is that the consistent and integrated leadership is pivotal to the successful pandemic handling. The case study is adopted as a strategy of inquiry, given it is an effective method for the in-depth understanding of a situation (Yin, 2018). In this scenario, the subject is the 'coordination of diverse stakeholders, governmental levels and sectors to contain the COVID-19' and the object is 'China'.

The term 'pandemic' was coined in 1666 (Harvey, 1674, p. 4) and led to disagreements around its meaning until recently (Altman, 2009). Then, the experts Morens, Folkers and Fauci (2009) defined pandemic by its characteristics: wide geographic extension, spread via transmission that can be traced from place to place, high attack rates and explosiveness, minimal population immunity, novelty (new diseases or novel variants of existing organisms), infectiousness and severity (Morens et al., 2009, pp. 1019-1020). Therefore, a pandemic requires fast response and complex preparation (Paules, Eisinger, Marston \& Fauci, 2020) both by health experts and public administration. From this perspective, the multi-level governance theory seems suitable to challenge, specially due to the fact that it organizes different agents in unlimited mixable levels according to task-specific needs, as explained in the literature review section.

The pandemic has been studied mainly the health field (Weiner, Balasubramaniam, Shah \& Javier, 2020, p. 148). Thus, research on government responses, especially related to the role of public leadership in facing pandemic is needed (Greer, King, Fonseca \& Peralta-Santos, 2020). On the other hand, it lacks studies on the multi-level governance applied to China and non-democracies (Hensengerth \& Lu, 2018, p. 2; Ongaro, Gong \& Jing, 2018, pp. 2-3). To sum up, those aspects highlight the relevancy of this research.

The first section presents China and Wuhan, the first pandemic epicenter. Then, the literature review focuses on multi-level governance theory. Subsequently, actions taken by China in the fight against COVID-19 were analyzed through the multi-level governance lens. In the last section, conclusions and opportunities for future developments are exposed, achieving the research's purpose. 


\subsection{People's Republic of China and Wuhan}

China (Zhōngguó 中国) is one of the greatest world powers, also known in the west as "Middle Kingdom" or "Land of the Red Dragon". With 1.4 billion inhabitants, it is the most populous country in the world (World Bank [WB], 2020a). By the GDP at US\$ 13.6 trillion in 2018 (WB, 2020b), China has the largest economy in Asia and the second in the world, just after the United States.

From the political angle, China "is a socialist state under the people's democratic dictatorship led by the working class and based on the alliance of workers and peasants" (People's Republic of China [PRC], 2004, art. 1) also grounded on the "principle of democratic centralism" (PRC, 2004, art. 3). However, the democracy index compiled annually by The Economist classifies China as an authoritarian nation, among the 15 least democratic among 167 countries (2020, p. 14). Similarly, scholars label the Chinese political system as authoritarian (Hensengerth \& Lu, 2018, p. 2; Nye, 2019, p. 8).

The Communist Party of China (CPC) (Zhōngguó Gòngchăndăng中国共产党) rules the country since 1949, when the People’s Republic of China (PRC) (Zhōnghuá rénmín gònghéguó中华人民共 和国) was established by the Chinese Communist Revolution (Zhōngguó rénmín jiěfàng zhànzhēng 中国人民解放战争), just after the civil war (Guógòng nèizhàn國共內戰). At the same time, the Constitution of the PRC (Zhōnghuá Rénmín Gònghéguó Xiànfă中华人民共和国宪法) adopts the multi-party system (PRC, 2004, art. 5). In reality, the CPC and the country's political structure are closely intertwined, which ensures institutional power to the party. Namely, Xi Jinping, President of the PRC since 2013, is also general secretary at the CPC, its highest position. The Premier Li Keqiang leads the State Council of China (Zhōngyāng rénmín zhèngfŭ zhèngwùyuàn中央人民政府政务院) and the central government.

FIGURE 1 PICTURE OF CHINA'S POLITICAL AND POWER STRUCTURE

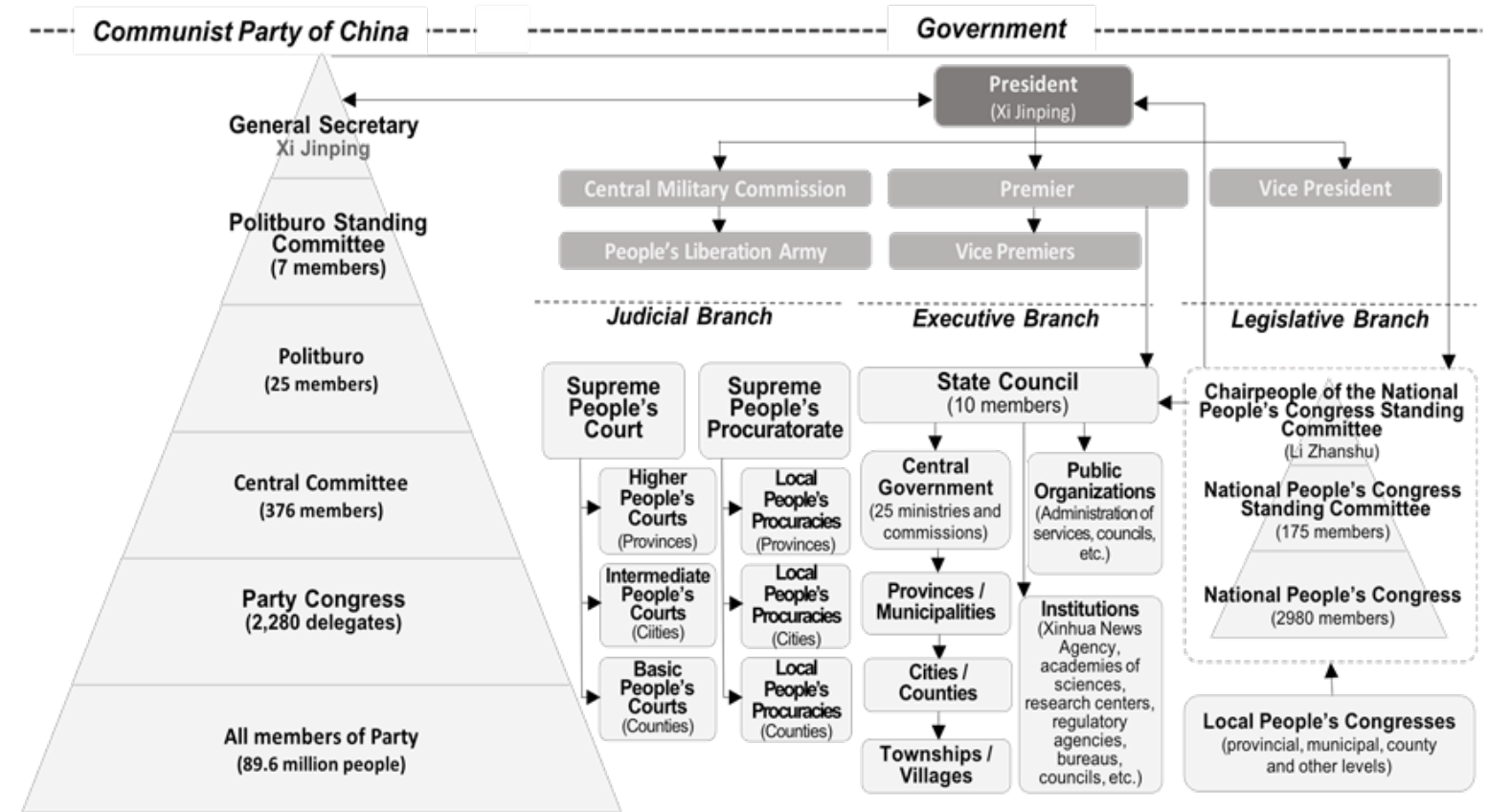

Source: Elaborated by the author based on Joseph (2019, pp. 210-214), Fernandes (2014, pp. 8-18), PRC (2004) and Communist Party of China (CPC, 2017). 
The country is divided into provinces (shěng省), which comprise cities (shì 市) with counties (xiàn 县). The first pneumonia cases of unknown etiology were detected in Wuhan City, Hubei Province, central region of China, in December 2019. The city of 11 million dwellers in 7 counties was the first pandemic epicenter.

The reference to dictatorship in the constitution and the CPC role in politics, often lead to the belief that a concentrated power domains China. Nevertheless, the Chinese political and power structure is complex, with legislative, executive and judicial branches spread in different levels from the central government (Fig. 1). Additionally, the Chinese economic reform (găigé käifàng改革开放) started in the 1970s, introduced the market economy alongside socialism. It has involved a new set of stakeholders (Fulda, Li \& Song, 2009), putting the diffusion of power forward (Hensengerth \& Lu, 2018, p. 2; Hess, 2013, pp. 81-82; Jing, 2015, p. 2). As an illustration, public goods are occasionally provided by NGOs at local level, like the elderly care in Nanjing's Gulou (Hensengerth, 2015, p. 304).

To sum up, contemporary China's strategies and plans involve different levels of government and several civil society actors. Thus, for successful results, a plethora of agents sometimes acting in different roles in different situations should be strictly integrated and organized to attend the pandemic emergency. In this context, the multi-level governance theory is useful for China's analysis as exposed in the next section.

\section{THEORETICAL FRAMEWORK}

\subsection{The Multi-Level Governance (MLG) Theory}

The notion of multi-level governance (MLG) was introduced by Marks in the 1990s to explain the decision making over European Community Funds in different government levels (Marks, 1992). The main point is the shift of the state-centric pattern to the collective decision making (Hooghe \& Marks, 2001, pp. 4-5).

Peters e Pierre state that MLG "refers to negotiated, non-hierarchical exchanges between institutions at the transnational, national, regional and local levels" (2001, p. 131). Indeed the MLG is grounded on common goals, highlights transnational institutions as mediators and nation states as pivotal in organizing the internal political structure, as well as in developing international politics (Hooghe \& Marks, 2001, p. 2).

The pattern favors horizontal arrangements integrated by subnational governments and private stakeholders aimed at policy formulation and implementation (Torfing, Peters, Pierre \& Sorensen, 2012, p. 19). Besides involving actors of multiple governamental tiers vertically coordinated, the MLG may increase the horizontal institutional capacities by coordinating diverse stakeholders (Peters \& Pierre, 2001, p. 133). Under those circumstances, the MLG enhances the legitimacy of measures and the potential for achieving objectives (Torfing et al., 2012, p. 87).

Jessop argues that the emergence of a global risk society and global threats, as well as the re-scaling of powers upwards, downwards or sideways demands a network-based governance approach (2013, p. 11). The characteristics of a pandemic, namely the wide geographic extension, the spread via transmission with high attack rates and explosiveness while there is a minimal 
population immunity require strong countermeasures involving a wide range of stakeholders of public and private sectors, domestically and internationally. Therefore, the nation state and the traditional bureaucracy cannot effectively meet this kind of challenge (Jessop, 2013, p. 11). The governance of functional interdependencies of complex networks with self-organization roles best suits in such cases (Jessop, 2013, p. 22). Under those circumstances, the MLG is suitable to face the pandemic of COVID-19.

Markedly, the MLG studies have developed with a twofold typology. The type I MLG is systematic, characterized by general-purpose jurisdictions and limited immixable levels. The type II MLG is flexible, characterized by task-specific jurisdictions and unlimited mixable levels (Ongaro, 2015, p. 3).

Moreover, Stephenson identifies five generations in the evolution of MLG studies (2013). The first, 'original uses' focuses on the interaction of levels in order to elaborate policies and decision-making and captures the term governance in opposition to government (Marks, 1992; Stephenson, 2013, pp. 819822). The second, 'functional uses' applies MLG beyond the European Union (EU) (Shair-Rosenfield, Marks \& Hooghe, 2014; Stephenson, 2013, pp. 822-823). The third, 'combined uses' considers tools of governance not only for policies elaboration, but also for implementation (Stephenson, 2013, pp. 823826). The fourth, 'normative uses' highlights issues related to legitimacy and accountability (Scharpf, 2007; Stephenson, 2013, pp. 826-827). Finally, the current trend, 'comparative uses' examines MLG in other cases beyond EU, including public-private partnerships and international institutions, such as the WHO (Cepiku, Jesuit \& Roberge, 2013; Daniell \& Kay, 2018; Stephenson, 2013, pp. 829-831).

In a contemporary view, Piattoni defined MLG as a theory of political mobilization and state structure development in which the supranational, national, subnational and local levels have authority over the corresponding territory, including the private stakeholders connected by common goals (Piattoni, 2010, pp. 23-28).

From this perspective, the MLG variation is observed in the space formed by the intersection of three axes corresponding to the domestic-international dimension, center-periphery dimension and the public-private dimension (Fig. 2). The axis $\mathrm{X}_{1}$ reflects the decentralization in the nation state, from center to periphery, like cities (Piattoni, 2010, p. 28). The axis $\mathrm{X}_{2}$ refers to movements between domestic and international cooperation (Piattoni, 2010, pp. 28-29). The axis $\mathrm{X}_{3}$ distinguishes public and private spheres, involving civil society, NGOs and companies (Piattoni, 2010, p. 29).

To put it differently, the intersection of axes $\mathrm{X}_{1}$ and $\mathrm{X}_{2}$ includes concerted actions of central government and subunits, like cities, provinces and counties towards domestic or international aims. For instance, climate change policies (Betsill \& Bulkeley, 2006), trade policies (Hawkins, Holden \& Mackinder, 2020) and measures for coping global diseases are included in this plan. The space formed by axes $\mathrm{X}_{2}$ and $\mathrm{X}_{3}$ refers to global actors in the domestic-international dimension. That is the case of multinational companies, international organizations and the international coalitions for advocacy. The plan at the intersection of axes $\mathrm{X}_{3}$ and $\mathrm{X}_{1}$ is domestic, consisting of governance arrangements among NGOs, companies, civil society and government of different levels. The starting point of the three axes (point 0 ) corresponds to the central government of the sovereign state. Finally, the plan of intersection among the three axes $\left(\mathrm{X}_{1} / \mathrm{X}_{2} / \mathrm{X}_{3}\right)$ is the variation space of horizontal and vertical structures of MLG. 


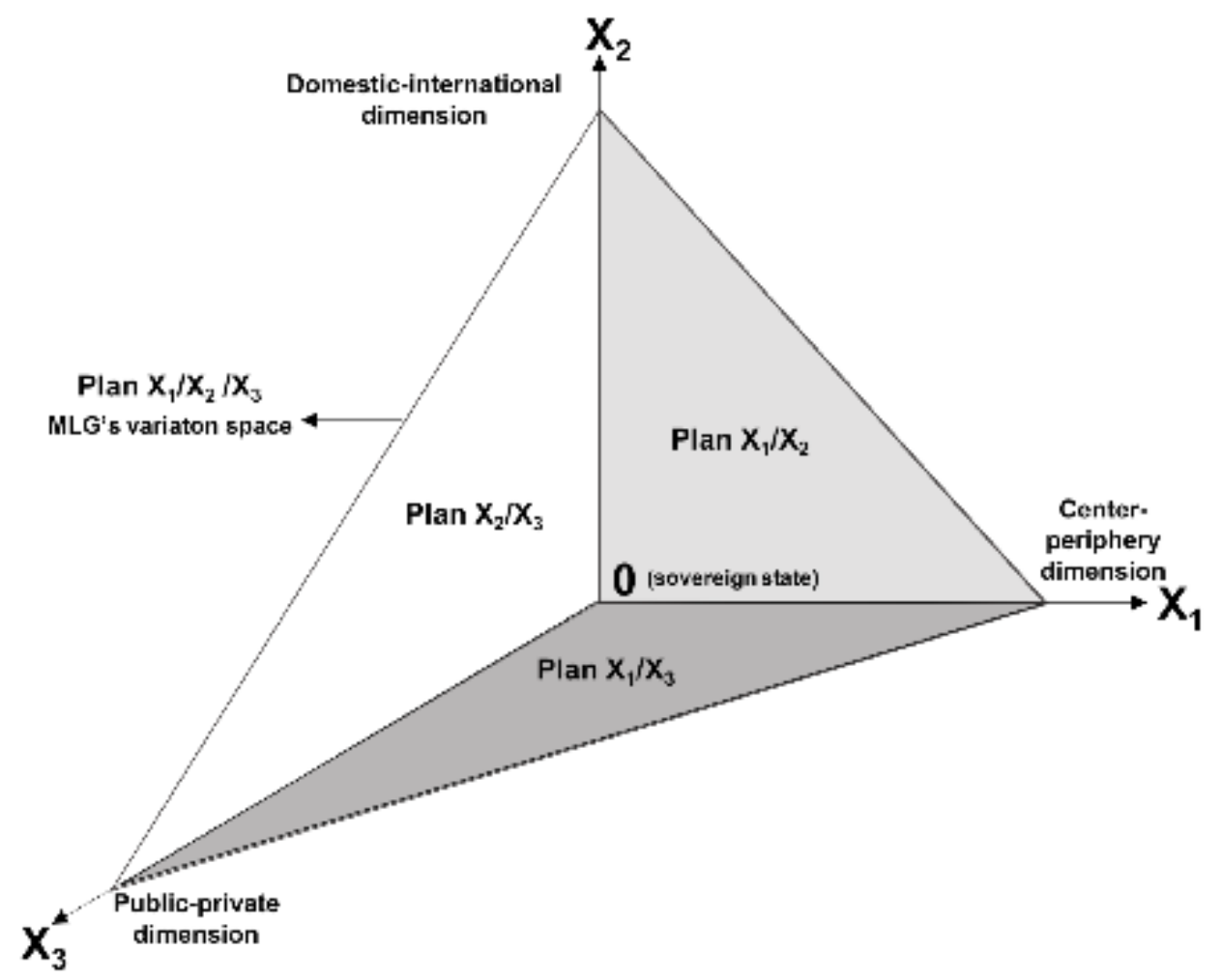

Source: Elaborated by the author based on Piattoni (2010, pp. 27-30).

Piattoni warns that MLG modalities are territorial and circumstantial rather than functional jurisdictions $(2010$, p. 30$)$. Therefore, this means that MLG redefines transitorily boundaries of territories and jurisdictions in order to achieve a common goal (Piattoni, 2010, p. 30). Usually, those provisions imply the rise of a formal or informal leadership according to purposes and activities to coordinate in networks, committees, working groups, and other similar structures (Piattoni, 2010, p. 30). Briefly, the 'three axes MLG matrix' by Piattoni is the analytical framework in this research.

\subsection{The Multi-Level Governance in China}

Scholars usually attribute the authoritarian hue to China (Hensengerth \& Lu, 2018, p. 2; Nye, 2019 , p. 8). On the other side, the MLG is perfectly compatible with democracies (Ongaro et al., 2018, pp. 10-11; Piattoni, 2015) given that it promotes collective postures (Hooghe \& Marks, 2001 , pp. 4-5). Hence, to pave the way to the analysis, some light should be shed on MLG in the Chinese scenario.

Hensengerth studied the central government's distribution of authority downwards, sideways and even upwards, in the case of the hydropower and environmental policy in China (2015). The author emphasizes that elaborating and implementing policies in China indeed involves power diffused among a wide range of political authorities and not the top-down approach inherent to 
authoritarian regimes (Hensengerth, 2015, pp. 301-302). This pattern had been encouraged by the Chinese reform (Jing, 2015, p. 2). Hence, the MLG unifies the decentralized political-administrative organization of China (Fig. 1).

The political economic system is self-proclaimed 'socialism with Chinese characteristics' (Zhōngguó tèsè shèhuì zhŭyi sīxiăng中国特色社会主义) (Ongaro et al., 2018, p. 12). Notably, some authors have identified variations of authoritarianism which feature democratic elements, such as the power divided into branches, elections and access to social media (Levitsky \& Way, 2002, pp. 54-58; Lewis, 2013, pp. 681-684). Those cases have been named "competitive authoritarianism" (Levitsky \& Way, 2002, p. 60), "pluralised authoritarianism" (Lewis, 2013, p. 681), "managed pluralism” (Balzer, 2003), "decentralized authoritarianism" (Landry, 2008), "resilient authoritarian" (Hensegerth, 2015, p. 325; Nathan, 2003), etc.

A research on the environmental protests in China revealed that governmental incentives and capacity building for local governments and civil society would improve MLG (Hensegerth \& Lu, 2018, pp. 18-19). On the other side, the 'Internet+' national strategy is highlighted as an example of the MLG potential in China (Jing \& Li, 2018). In that research, Jing and Li mapped the actors' roles in the Chinese MLG: mediating, brokering, leveraging and coordinating (2018, pp. 7-12). Mediating is promoting the flow of information for priority policy issues, strengthening the governance (2018, pp. 7-8). Coordinating means to ensure implementation resources by running central policies while organizing the teamwork (2018, p. 11). Then, brokering refers to the intermediation of systematic knowledge and creation of belief coalitions towards the balancing point $(2018$, p. 9). Finally, leveraging is about enhancing social awareness of policies especially by communication, education, motivation of citizens and similar actions (2018, p. 10). In the MLG, assignment of roles occurs according to skills and potential performance, which may increase successful actions.

Ongaro et al. state that "the development of MLG has been reshaping the traditional view of public policy and administration in China that relies solely on mechanisms of hierarchy, publicness, and sovereignty" (2018, p. 2). In fact, the political decentralization, economic openness, search of legitimacy and focus on performance are foundational for Chinese public governance, opening doors for vertical, horizontal, public and private collaboration. (Ongaro et al., 2018, p. 13). Under those circumstances, the MLG is instrumental in preserving and strengthening the Chinese regime (2018, p. 13).

Thus, this research analyses the leadership of China to contain the pandemic by the 'three axes MLG matrix' (Piattoni, 2010) with the 'roles of MLG matrix' (Jing \& Li, 2018).

\section{RESEARCH DESIGN}

The study investigates the leadership of China over intergovernmental and private actions in tackling the COVID-19. In this regard, the research design aims to answer two questions: [1] from which levels and sectors are the actors involved in tackling the COVID-19? and [2] what are the roles played by those actors? The main argument is that the successful control of the pandemic depends on the effective leadership over different levels. Therefore, the literature review aligned the works of Piattoni (2010), Jing and $\mathrm{Li}$ (2018) to build the analytical framework. 
The case study is the strategy of inquiry in order to answer 'which' and 'what' questions, as well as to gain detailed understanding over the situation (Yin, 2018, pp. 33-34). The subject is the 'leadership and coordination over actions, multiple tiers actors and sectors in order to contain the COVID-19'. As a key case, 'China' is the object of analysis (Thomas, 2016, pp. 15-16, pp. 98-102).

China was the first country to face the pandemic. The first cases of pneumonia of unknown etiology were reported to the WHO Office by Wuhan health authorities on December 31, 2019. The outbreak evolved rapidly in January 2020. Until 3, 44 cases have been identified in China and the first related death occurred on 11. Other nations, including Thailand, Japan, Korea and the United States unveiled initial cases between 13-20. Then, China reported to WHO the causal agent associated with exposures in the Huanan seafood wholesale market (Wǔhàn Huánán hăixiān pīfā shìchăng武汉华 南海鲜批发市). The WHO declared a global health emergency on January 30 and the pandemic on March 11. China brought the disease under control in March (Ghebreyesus, 2020). As of 5 October 2020, 34.8 million cases and more than one million deaths were reported around the world (WHO, 2020c) and they are likely to have increased until publication of this study.

To promote objectivity and consistency, this paper adopts the triangulation of sources (Yin, 2018, pp. 78-82). Besides that, a logic model guides data collection and analysis (Flick, 2007, pp. 2, pp. 1516; Yin, 2018, pp. 78-82), namely it uses content analysis technique (Krippendorff, 2003).

First, actions of China in fighting COVID-19 from December 31, 2019 to March 31, 2020 were identified from reports issued by Chinese government (Chinese Academy of Sciences [CAS], 2020) and by WHO (2020a, 2020b). The international media provided complementary information about those actions. The result is a sample $(n)$ of 374 actions. Secondly, they were categorized by coding technique (Krippendorff, 2004, pp. 99-101, 129-137) guided by the 'three axes MLG matrix' (Piattoni, 2010) and the 'roles of MLG matrix' (Jing \& Li, 2018, pp. 7-12).

BOX 1

EXAMPLES OF DATA CODING

\begin{tabular}{|c|c|c|c|c|c|c|}
\hline & & & & & MLG Axis & Role \\
\hline Action & Date & Agent & Sector & Level & $\begin{array}{c}(0)\left(X_{1} / X_{2}\right) \\
\left(X_{2} / X_{3}\right)\left(X_{3} / X_{1}\right)\end{array}$ & $\begin{array}{l}\text { (M) (B) } \\
\text { (L) (C) }\end{array}$ \\
\hline $\begin{array}{l}\text { The Wuhan Municipal Health } \\
\text { Commission released a briefing } \\
\text { confirming } 27 \text { cases and asking } \\
\text { population to avoid closed places and } \\
\text { gatherings, as well as to use masks on } \\
\text { streets }\end{array}$ & $\begin{array}{c}\text { Dec. 31, } \\
2019\end{array}$ & $\begin{array}{c}\text { Wuhan } \\
\text { Municipal } \\
\text { Health } \\
\text { Commission }\end{array}$ & Public & Municipal & $x_{1} / X_{2}$ & B \\
\hline $\begin{array}{l}\text { China government informed the WHO } \\
\text { about progress in determining the } \\
\text { cause of the viral pneumonia in Wuhan }\end{array}$ & Jan. 9, 2020 & $\begin{array}{l}\text { Central } \\
\text { government } \\
\text { of China }\end{array}$ & Public & National & 0 & M \\
\hline
\end{tabular}




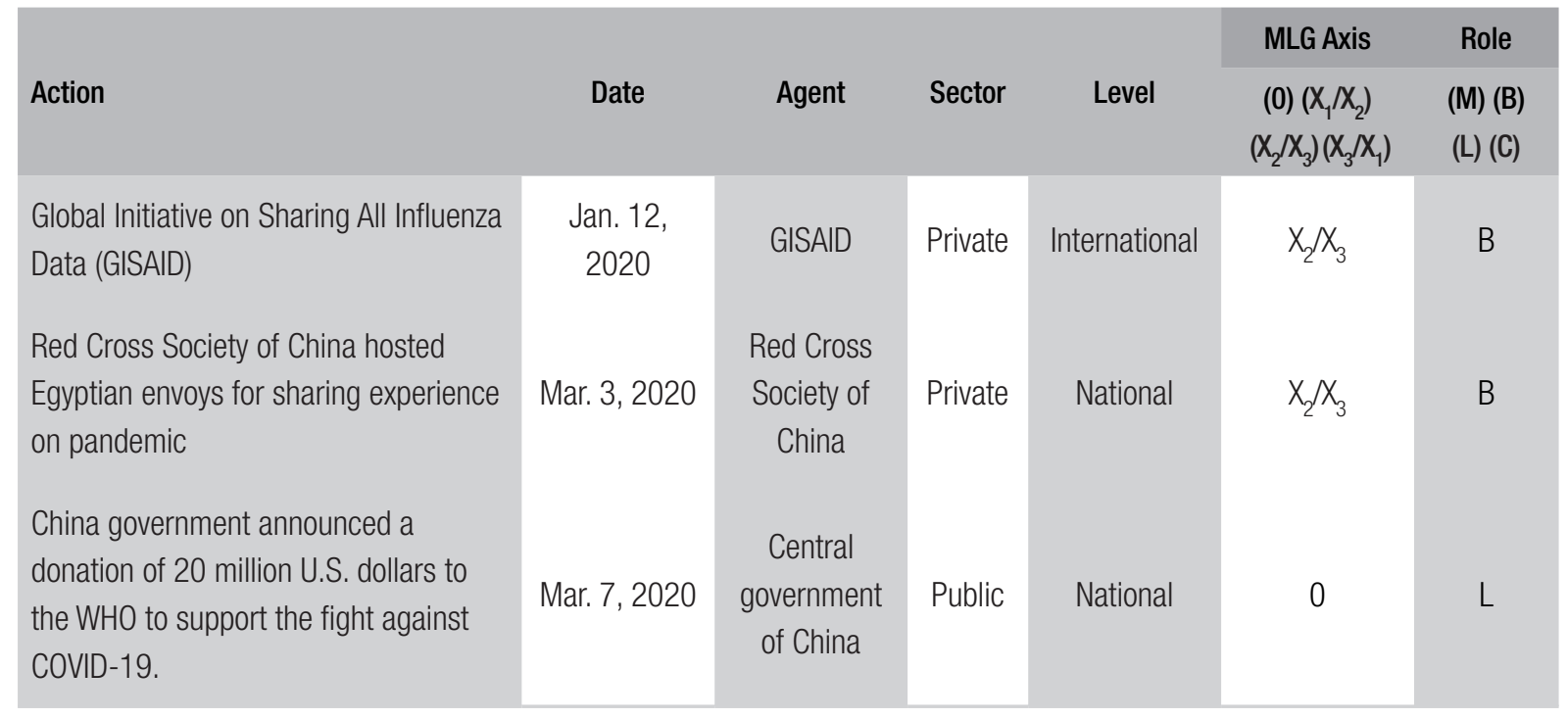

Source: Elaborated by the authors on working sheet of categorization/coding.

The categorization was plotted in a working sheet with seven columns: (1) description of action, (2) date, (3) Agent, (4) sector, (5) level, (6) MLG axis, (7) role, as examples on Box 1. The fifth column mentions the level of agents (national, provincial, municipal, international, party). In the sixth column, actions were coded among four options which are 0 : national government, $\mathrm{X}_{1} / \mathrm{X}_{2}$ : government in domestic or international domains, $\mathrm{X}_{2} / \mathrm{X}_{3}$ : private actors in domestic or international domains or $\mathrm{X}_{3} /$ $\mathrm{X}_{1}$ : government or private actors in domestic domain. Finally, the last column identifies which of the four roles is led by agent: mediating, brokering, leveraging or coordinating.

Lastly, quantitative and qualitative findings resulted from working sheets. The frequency criteria (Krippendorf, 2004, pp. 128-129) guided the qualitative analysis. Next section presents findings and discussion.

\section{FINDINGS AND DISCUSSION}

Quantitative findings are summarized in Table 1. In regard to the 'three axes MLG matrix', the most frequent results are in 'Point 0 ' and in axis ' $\mathrm{X}_{1} / \mathrm{X}_{2}$ ' that respectively means 138 actions of sovereign state and 195 actions of government in domestic and international dimensions. On the other hand, brokering and leveraging were the most frequent roles of agents in China during the COVID-19 pandemic. Next paragraphs describe and analyze qualitative findings. 


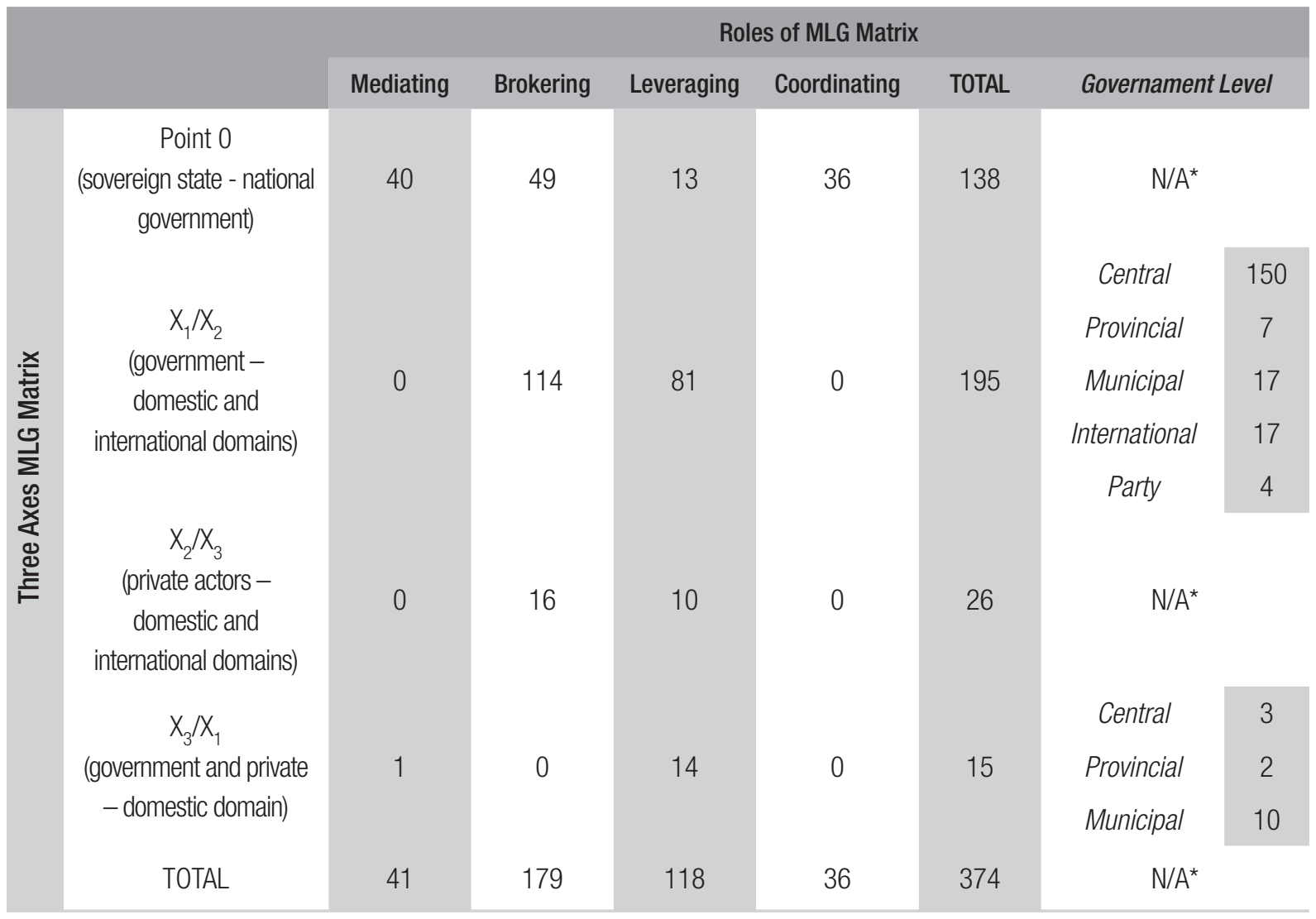

${ }^{\star}$ N/A: Not applicable.

Source: Elaborated by the author on working sheet of categorization/coding.

Actions of President Xi Jinping, Premier Li Keqiang and the State Council, chaired by Premier were clustered in 'point 0 '. The President performed in 'mediating'. Besides the guidance, for instance when determining priority on people's safety and health and the path to the economic recovery, Xi Jinping also dealt with foreign affairs, by contacting actively other heads of state, like the United States, Germany, Cambodia, Saudi Arabia, and the list goes. Therefore, the President Xi Jinping was domestically and internationally active by mediating and leveraging actions.

In compliance with Xi Jinping guidelines (CAS, 2020), the government set the 'central leading group for COVID-19 prevention and control' (CLGCPC) (Zhōngyāng yingduì xīnxíng guānzhuàng bingdú gănrăn fèiyán yìing gōngzuò lǐngdăo xiăozǔ中央应对新型冠状病毒感染肺炎疫情工作领 导小组), chaired by Premier Li Keqiang (Xinhua, 2020). Hence, the Premier was in the 'coordinating' role, which also made him the government's spokespeople at daily press conferences held in Beijing.

The analysis unveiled that $52 \%$ (195) of actions were led by the public sector ( $\mathrm{plan} \mathrm{X}_{1} / \mathrm{X}_{2}$ ) In fact, governmental entities linked to the central government developed $40 \%$ of total actions (150). As an illustration, the National Health Commission (NHC) (Zhōnghuá rénmín gònghéguó guójiā wèishēng jiànkāng wěiyuánhui中华人民共和国国家卫生健康委员会), with ministry status, stood out in the 'leveraging' role while developing technical activities, such as diagnosis and treatment guidelines, 
capacity building programs and technical missions in Wuhan. Additionally, the NHC also was in the 'brokering' role by the facilitation of virtual meetings of international experts aimed mainly at sharing experiences. Similarly, the Chinese Center for Disease Control and Prevention (CDC) (Zhōngguó jíbing yùfáng kòngzhì zhōngxin 中国疾病预防控制中心) linked to the NHC, was in charge of research issues, like the isolation of the virus strain and scientific publications.

Provinces were in the 'leveraging' role when ensuring medical supplies and essential commodities to Hubei, under the CLGCPC coordination. Equally, Wuhan was the 'leveraging' role. As an illustration, the city realized testing, built field hospitals, issued restrictive measures towards transportation and masking, among other actions. Given the intricate relationship with the Chinese government, the CPC appeared in the 'leveraging' category due to the realization of seminars and technical missions.

In this axis, even the international level got mobilized, especially through brokering and leveraging roles. For instance, WHO was in the leveraging role when it led the international mission involving more than 20 foreign experts to China in February 2020 (2020a, p. 16). As well, the executive director of the WHO Health Emergencies Programme, in the brokering role, confirmed Chinese efforts towards international cooperation to the fight against COVID-19 when Larry Kudlow, director of the National Economic Council of US accused China of lack of transparency (Stanglin, 2020). In this regard, concerns around the dubious role played by the WHO (Campbell \& Gunia, 2020) dissipated when other credible international agents also conferred legitimacy to the Chinese efforts. That is the case of scientific editors, researchers and international universities (AlTakarli, 2020; Castañón \& Esomonu, 2020; Cyranoski 2020; Maier \& Brockmann, 2020; The Lancet, 2020).

The plan $\mathrm{X}_{2} / \mathrm{X}_{3}$ features 26 measures of 'brokering' and 'leveraging', which include international lectures of the Chinese pneumologist Zhong Nanshan alongside measures by civil society organizations. As an example, the Red Cross Society of China (Zhōngguó hóng shízi hui中国红十字会) sent medical teams and supplies to more than 100 countries and international organizations. By the same token, private hospitals trained Chinese medical teams for international missions.

Finally, the plan $\mathrm{X}_{3} / \mathrm{X}_{1}$ aggregates 15 actions, mainly in the 'leveraging' category, involving private companies partnering with the public sector to provide innovative solutions. That is the case of CloudMinds (Dá tà kēji达阉科技) which donated $5 \mathrm{G}$ robots for hospitals disinfection and medicines delivery, reducing risks of contamination. Also, the Shenzhen Smart Drone (Zhì háng wú rén jiz智航 无人机) and the Shenzhen MicroMultiCopter (Kēb区 tè hángkōng科比特航空) provided drones for patrolling isolation and masking on the streets, transporting samples, besides measuring temperatures and disinfecting streets.

Another important point is the diverse roles of the same actors. For instance, the president Xi Jinping was in mediating roles in meetings with WHO and contacts with foreign political leaders, but was in a leveraging role while visiting Wuhan to inspect the prevention and control work at the critical stage. Similarly, the Chinese Center for Disease Control and Prevention (CDC) acted in brokering and leveraging. The first, for instance, when facilitating a video meeting on COVID-19 involving about 200 health officials and experts from Asia and Africa. An example of the second is the pathogen identification from samples of patients. Clearly, the fast response required by the pandemic emergency has demanded involvement of agents in multiple roles. In this regard, the multilevel governance explains the pattern in as much as it is characterized by task-specific jurisdictions for each action. 
The unlimited mixable levels as feature of MLG means vertical and horizontal coordination of agents. In this context, government levels, especially institutions linked to the central government, provinces and the Wuhan city got vertically interlinked through different roles due to fight against COVID-19. Private actors were horizontally coordinated and acted in 'leveraging' and 'brokering', mainly through actions related to technology, sharing the same common goal. Additionally, the involvement of international stakeholders was relevant to conferring legitimacy to China's activities when criticisms emerged internationally. Therefore, coping the pandemic emergency required great coordination among vertical and horizontal agents and solutions were collectively held with great political mobilization. Hence, the pursuit of the shared goal redefined transitorily boundaries of jurisdictions and determined roles of agents. To sum up, the analysis demonstrated a consistent dialog between the MLG theory and the Chinese in the fight against COVID-19.

\section{CONCLUSION}

The COVID-19 pandemic, which affected 34.8 million people and caused more than one million deaths worldwide until October 5, 2020, had the first epicenter in Wuhan, in Hubei Province from January 2020. Two months later, the control over the pandemic by China was internationally recognized. Thus, grounded on the argument that the public leadership was fundamental to the successful achievement, this article analyzed the Chinese actions, taking the multi-level governance theory as an analytical framework.

The challenge involved asymmetrical power relations among levels of government and private actors in domestic and international dimensions. Indeed, a complex network involving the city of Wuhan, provinces and central government entities, also involving the private sector, especially companies, civil society organizations, citizens and international actors was constituted in China to face the pandemic.

Under the guidance of President Xi Jinping and coordination of the Premier, the Chinese MLG system to tackle COVID-19 involved private entities horizontally and the different government levels vertically, with predominance of the central government. Even international agents got involved and, in a certain way, favored China when international criticisms emerged. This finding gave the answer to the first research question.

Additionally, the answer to the second question showed that 'coordinating' is restricted to the Premier and 'mediating' to the President Xi Jinping, while other actors worked on 'brokering' and 'leveraging'. As well, there were cases of the same agents in different roles. Indeed, the emergency and severity imposed by the pandemic required involvement of multiple actors in unlimited mixable levels organized according to task-specific needs. Thus, MLG rises as a suitable approach. In a public health emergency, the coordination by the nation state is the most obvious outcome. However, it is the well-integrated and well-oiled wheels among different levels and sectors that led to the fast and effective control over the pandemic.

Future developments could explore in detail how the coordination of horizontal and vertical levels took place in sub-actions, such as the construction of hospitals, as well as whether there is room for coordination of those sub-actions by private actors in China. 
To sum up, the MLG is more than a simple analytical tool, indeed, it is an effective model of public leadership that offers integration, alignment and legitimacy, bringing together potential actors around common goals. The MLG enhances the efforts and the performance in challenging contexts. Thus, it is a promising paradigm in coping with the COVID-19 pandemic and similar challenges around the world. 


\section{REFERENCES}

AlTakarli, N. S. (2020). China's Response to the COVID-19 Outbreak: A Model for Epidemic Preparedness and Management. Dubai Medical Journal, 2(3), 44-49. Retrieved from https://doi. org/10.1159/000508448

Altman, L. (2009, June 08). Is this a pandemic? Define 'pandemic'. Ney York Times. Retrieved from https://www.nytimes.com/2009/06/09/ health/09docs.html?auth=login-email\&login=email

Balzer, H. (2003, July). Managed pluralism Vladimir Putin's emerging regime. Post-Soviet Affairs, 19(3), 189-227.

Betsill, M., \& Bulkeley, H. (2006). Cities and the multilevel governance of global climate change. Global Governance, 12(2), 141-159.

Breuninger, K. (2020, April 01). China hid extent of coronavirus outbreak, US intelligence reportedly says. CNBC. Retrieved from https://www.cnbc. com/2020/04/01/coronavirus-china-hid-extent-ofoutbreak-us-intelligence-reportedly-says.html

Campbell, C., \& Gunia, A. (2020, April 01). China says it's beating coronavirus: but can we believe its numbers? Time. Retrieved from https://time. com/5813628/china-coronavirus-statistics- wuhan/

Campbell, K. M., \& Doshi, R. (2020, March 18). The coronavirus could reshape global order. Foreign Affairs. Retrieved from https://www.foreignaffairs. com/articles/china/2020-03-18/coronavirus-couldreshape-global-order

Castañón, L., \& Esomonu, E. (2020, June 29). Researchers examine why the U.S. hasn't had the same success as China in slowing the spread of the coronavirus. Medical Xpress. Retrieved from https:// medicalxpress.com/news/2020-06-hasnt-successchina-coronavirus.html [Acessed 25 jul. 2020].

Cepiku, D., Jesuit, D. K., \& Roberge, I. (Eds.). (2013). Making multilevel public management work. Boca Raton, FL: CRC Press.

Chinese Academy of Sciences (Zhōngguó kēxué yán jiù yuàn中国科学研究院). (2020). China publishes timeline on COVID-19 information sharing, int'l cooperation. Retrieved from http://english.cas.cn/ newsroom/news/202004/t20200407_232185.shtml

Communist Party of China (Zhōngguó gòngchăndăng中国共产党). (2017). Constitution of the Communist Party of China. Retrieved from http://www.china.org.cn/20171105-001.pdf

Cyranoski, D. (2020). What China's coronavirus response can teach the rest of the world. Nature, 579(7800), 479-480.

Daniell, K., \& Kay, A. (Eds.). (2018). Multi-level governance: conceptual challenges and case studies from Australia. Canberra, Australia: ANU Press.

Fernandes, T. M-S. (2014). Conhecendo o sistema político chinês [Getting to know the Chinese political system]. Brasília, DF: APEX-Brasil.

Flick, U. (2007). Managing quality in qualitative research. London, UK: Sage.

Fulda, A., Li, Y., \& Song, Q. (2009, September). How to gain trust and promote system innovation: strategies of Chinese civil society organisations collaborating with the government (Discussion Paper 52). Nottingham, UK: School of Contemporary Chinese Studies at The University of Nottingham.

Ghebreyesus, T. A. (2020, March 09). WHO Director-general's opening remarks at the media briefing on COVID-19 - 9 March 2020. WHO. Retrieved from https://www.who.int/dg/speeches/ detail/who-director-general-s-opening-remarksat-the-media-briefing-on-covid-19---9-march-2020

Graham-Harrison, E., \& Kuo, L. (2020, March 19). China's coronavirus lockdown strategy: brutal but effective. The Guardian. Retrieved from https:// www.theguardian.com/world/2020/mar/19/chinascoronavirus-lockdown-strategy-brutal-but-effective

Greer, S., King, E., Fonseca, E., \& Peralta-Santos, A. (2020). The comparative politics of COVID-19: the need to understand government responses. Global Public Health, 15(9), 1413-1416.

Harvey, G. (1674). Morbus Anglicus: or the anatomy of consumptions. London, UK: Nathanael Book. Retrieved from https:/quod.lib.umich.edu/cgi/t/ text/text-idx?c=eebo;idno=A43020.0001.001

Hawkins, B., Holden, C., \& Mackinder, S. (2020). The battle for standardized cigarette packaging in Europe. London, UK: Palgrave.

Hensengerth, O. (2015). Multi-level governance of hydropower in China? The problem of transplanting a western concept into the Chinese governance 
context. In E. Ongaro (Ed.), Multi-level governance: the missing linkages (pp. 295-320). Bingley, UK: Emerald.

Hensengerth, O., \& Lu, Y. (2018). Emerging environmental multi-level governance in China? Environmental protests, public participation and local institution-building. Public Policy and Administration, 34(2), 121-143.

Hess, S. (2013). Authoritarian Landscapes: popular mobilization and the institutional sources of resilience in nondemocracies. New York, NY: Springer.

Hooghe, L., \& Marks, G. (2001). Multi-level governance in the European Union. In L. Hooghe \& G. Marks (Ed.), Multi-level governance and European integration (pp. 1-32). Lanham, MD: Rowman \& Littlefield Publishers.

Jessop, B. (2013). Hollowing out the 'nation-state' and multi-level governance. In P. Kennett (Ed.), The handbook of comparative social policy (2th ed., pp. 11-26). Cheltenham, UK: Elgar.

Jing, Y. (2015). The road to collaborative governance in China. In Y. Jing (Ed.), Governing China in the $21^{\text {st }}$ century: the road to collaborative governance in China (pp. 1-20). New York, NY: Palgrave.

Jing, Y., \& Li, D. (2018). Private roles in enhancing multi-level governance: China's "Internet+" national strategy. Public Policy and Administration, 34(2), 144-164.

Joseph, W. A. (2019). Politics in China: an introduction (3rd ed.) London, UK: Oxford University Press.

Krippendorff, K. (2003). Content analysis: an introduction to its methodology (2nd ed.). London, UK: Sage.

Landry, P. F. (2008). Decentralized authoritarism in China: the Communist Party's control of local elites in the post-Mao era. Cambridge, UK: Cambridge University Press.

Levitsky, S., \& Way, L. A. (2002, April). The rise of competitive authoritarism. Journal of Democracy, 13(2), 51-65.

Lewis, O. (2013). Net inclusion: new media's impact on deliberative politics in China. Journal of Contemporary Asia, 43(4), 678-708.

Maier, B., \& Brockmann, D. (2020). Effective containment explains subexponential growth in recent confirmed COVID-19 cases in China. Science, 368(6492),742-746.

Marks, G. (1992). Structural policy in the European Community. In A. Sbragia (Ed.), Euro-politics: institutions and policymaking in the "new" European Community (pp. 191-224). Washington, DC: Brookings.

Morens, D., Folkers, G., \& Fauci, A. (2009). What is a pandemic? The Journal of Infectious Diseases, 200(7), 1018-1021.

Nathan, A. J. (2003, January). China's changing of the guard: authoritarian resilience. Journal of Democracy, 14(1), 6-17.

Nye, J., Jr. (2019). Soft power and public diplomacy revisited. The Hague Journal of Diplomacy, 14(1-2), 7-20.

Ongaro, E. (2015). Multi-level governance: the missing linkages. In E. Ongaro (Ed.), Multi-level governance: the missing linkages (pp. 1-14). Bingley, UK: Emerald.

Ongaro, E.; Gong, T., \& Jing, Y. (2018). Toward multilevel governance in China? Coping with complex public affairs across jurisdictions and organizations. Public Policy and Administration, 34(2), 105-120.

Paules, C., Eisinger, R., Marston, H., \& Fauci, A. (2017). What recent history has taught us about responding to emerging infectious disease threats. Annals of Internal Medicine, 167(11), 805-811. Retrieved from http://doi.org/10.7326/M17-2496

People's Republic of China (Zhōnghuá rénmín gònghéguó中华人民共和国). (2004). Constitution of the People's Republic of China. Retrieved from http:// www.npc.gov.cn/zgrdw/englishnpc/ Constitution/ node_2825.htm

Peters, B., \& Pierre, J. (2001). Developments in intergovernmental relations: towards multi-level governance. Policy \& Politics, 29(2), 131-135.

Piattoni, S. (2010). The theory of multi-level governance: conceptual and normative challenges. Oxford, UK: Oxford University Press.

Piattoni, S. (2015). Multi-level governance: underplayed features, overblown expectation and missing linkages. In E. Ongaro (Ed.), Multi-level governance: the missing linkages (pp. 321-338). Bingley, UK: Emerald. 
Scharpf, F. W. (2007, July). Reflections on multilevel legitimacy (MPIfG working paper, $\mathrm{n}$. 07/3). Köln, Germany: Max-Planck-Institut für Gesellschaftsforschung.

Shair-Rosenfield, S., Marks, G., \& Hooghe, L. A. (2014). A comparative measure of decentralization for Southeast Asia. Journal of East Asian Studies, 14(1), 85-107.

Stanglin, D. (2020). China is cooperating on coronavirus, WHO expert says, disputing White House claims. USA Today. Retrieved from https:// www.usatoday.com/story/news/world/2020/02/14/ coronavirus-outbreak-china-transparency-whopoliticizing-white-house-official/4759427002/

Stephenson, P. (2013). Twenty years of multi-level governance: 'where does it come from? What it is? Where is it going?' Journal of European Public Policy, 20(6), 817-837.

The Economist. (2020). Democracy Index 2019: A year of democratic setbacks and popular protest. London, UK: The Economist Intelligence Unit.

The Lancet. (2020, July 25). COVID-19 and China: lessons and the way forward. The Lancet, 396(10246), 213.

Thomas, G. (2016). How to do your case study (2nd ed.). London, UK: Sage.

Torfing, J., Peters, B. G., Pierre, J., \& Sorensen, E. (2012). Interactive governance: advancing the paradigm. Oxford, UK: Oxford University Press.

Weiner, D., Balasubramaniam, V., Shah, S., \& Javier, J. (2020). COVID-19 impact on research, lessons learned from COVID-19 research, implications for pediatric reserch. Pediatric Research, 88(2),148-150.
World Bank. (2020a). Population, total: China. The World Bank Data. Retrieved from https:// data.worldbank.org/indicator/SP.POP. TOTL?locations=CN\&most_recent_value_desc=true

World Bank. (2020b). GDP (current, US\$): China. The World Bank Data. Retrieved from https:// data.worldbank.org/indicator/NY.GDP.MKTP. $\mathrm{CD}$ ?locations $=\mathrm{CN}$

World Health Organization. (2020a). Report of the WHO-China joint mission on coronavirus disease 2019 (COVID-19). WHO. Retrieved from https:// www.who.int/docs/default-source/coronaviruse/whochina-joint-mission-on-covid-19-final-report.pdf

World Health Organization. (2020b). Novel coronavirus (2019-nCoV): situation report 1 21 january 2020. WHO. Retrieved from https:// www.who.int/docs/default-source/coronaviruse/ situation-reports/20200121-sitrep-1-2019-ncov. pdf?sfvrsn=20a99c10_4

World Health Organization. (2020c). Coronavirus disease (COVID-19): data as received by WHO from national authorities as of 04 October 2020. WHO. Retrieved from https://www.who.int/docs/defaultsource/coronaviruse/situation-reports/20201005weekly-epi-update-8.pdf [Accessed 9 Oct. 2020].

Xinhua. (2020, January 26). 李克强主持召开中央 应对新型冠状病毒感染肺炎疫情工作领导小组 会议 [Lǐkèqiáng zhǔchí zhàokāi zhōngyāng yìngduì xīnxíng guānzhuàng bìngdú gănrăn fèiyán yìqíng gōngzuò lǐngdăo xiăozŭ huìì Li Keqiang chaired the central leading group for COVID-19 prevention and control]. 新华网 [Xīnhuá wăng Xinhua]. Retrieved from http://www.xinhuanet.com/politics/202001/26/c_1125504004.htm

Yin, R. (2018). Case study research and applications: design and methods (6th ed.). London, UK: Sage.

\section{Niedja de Andrade e Silva Forte dos Santos}

https://orcid.org/0000-0002-7313-2296

Ph.D. Candidate in International Relations at University of Lisbon; Researcher at the Centre for Public Administration and Public Policies of the Institute of Social and Political Sciences, University of Lisbon (CAPP/ ISCSP/ULisboa).E-mail: niedjasantos@edu.ulisboa.pt; niedjasantos@icloud.com 